Article

\title{
Preparation of $\mathrm{Li}_{3} \mathrm{PS}_{4}-\mathrm{Li}_{3} \mathrm{PO}_{4}$ Solid Electrolytes by Liquid-Phase Shaking for All-Solid-State Batteries
}

\author{
Nguyen H. H. Phuc*(D), Takaki Maeda, Tokoharu Yamamoto, Hiroyuki Muto and Atsunori Matsuda *(D) \\ Department of Electrical and Electronic Information Engineering, Toyohashi University of Technology, \\ 1-1 Hibarigaoka, Tempaku, Toyohashi, Aichi 441-8580, Japan; maeda.takaki.px@tut.jp (T.M.); \\ tktut2@gmail.com (T.Y.); muto@ee.edu.tut.ac.jp (H.M.) \\ * Correspondence: nguyen.huu.huy.phuc.hr@tut.jp (N.H.H.P.); matsuda@ee.tut.ac.jp (A.M.); \\ Tel.: +81-532-44-6800 (A.M.); Fax: +81-532-48-583 (A.M.)
}

check for

updates

Citation: Phuc, N.H.H.; Maeda, T.; Yamamoto, T.; Muto, H.; Matsuda, A. Preparation of $\mathrm{Li}_{3} \mathrm{PS}_{4}-\mathrm{Li}_{3} \mathrm{PO}_{4}$ Solid Electrolytes by Liquid-Phase Shaking for All-Solid-State Batteries. Electron. Mater. 2021, 2, 39-48. https:// doi.org/10.3390/electronicmat2010004

Received: 2 February 2021

Accepted: 6 March 2021

Published: 12 March 2021

Publisher's Note: MDPI stays neutral with regard to jurisdictional claims in published maps and institutional affiliations.

Copyright: (c) 2021 by the authors. Licensee MDPI, Basel, Switzerland. This article is an open access article distributed under the terms and conditions of the Creative Commons Attribution (CC BY) license (https:// creativecommons.org/licenses/by/ $4.0 /)$.

\begin{abstract}
A solid solution of a $100 \mathrm{Li}_{3} \mathrm{PS}_{4} \cdot x \mathrm{Li}_{3} \mathrm{PO}_{4}$ solid electrolyte was easily prepared by liquidphase synthesis. Instead of the conventional solid-state synthesis methods, ethyl propionate was used as the reaction medium. The initial stage of the reaction among $\mathrm{Li}_{2} \mathrm{~S}, \mathrm{P}_{2} \mathrm{~S}_{5}$ and $\mathrm{Li}_{3} \mathrm{PO}_{4}$ was proved by ultraviolet-visible spectroscopy. The powder X-ray diffraction (XRD) results showed that the solid solution was formed up to $x=6$. At $x=20$, XRD peaks of $\mathrm{Li}_{3} \mathrm{PO}_{4}$ were detected in the prepared sample after heat treatment at $170{ }^{\circ} \mathrm{C}$. However, the samples obtained at room temperature showed no evidence of $\mathrm{Li}_{3} \mathrm{PO}_{4}$ remaining for $x=20$. Solid phosphorus-31 magic angle spinning nuclear magnetic resonance spectroscopy results proved the formation of $\mathrm{aOS}_{3}{ }^{3-}$ unit in the sample with $x=6$. Improvements of ionic conductivity at room temperature and activation energy were obtained with the formation of the solid solution. The sample with $x=6$ exhibited a better stability against $\mathrm{Li}$ metal than that with $x=0$. The all-solid-state half-cell employing the sample with $x=6$ at the positive electrode exhibited a better charge-discharge capacity than that employing the sample with $x=0$.
\end{abstract}

Keywords: liquid-phase synthesis; solid state electrolytes; all-solid-state battery; UV-Vis

\section{Introduction}

$\mathrm{Li}_{3} \mathrm{PS}_{4}$ is one of the most important substances in the fields of sulfide-based solid electrolytes and all-solid-state batteries because of its ease of preparation and application. In general, $\mathrm{Li}_{3} \mathrm{PS}_{4}$ has three different crystal structures and an amorphous (glass) state [1,2]. The ionic conductivity and air stability of $\mathrm{Li}_{3} \mathrm{PS}_{4}$ can also be easily tuned by the addition of different materials, i.e., oxides, nitrides and halogens. The addition of an appropriate amount of $\mathrm{LiI}$ into the $\mathrm{Li}_{3} \mathrm{PS}_{4}$ structure is known to boost its ionic conductivity from approximately $5.0 \times 10^{-4} \mathrm{~S} \mathrm{~cm}^{-1}$ to $6.5 \times 10^{-4} \mathrm{~S} \mathrm{~cm}^{-1}$ [3,4]. Ambient air stability or suppression of $\mathrm{H}_{2} \mathrm{~S}$ evolution is also improved with the existence of LiI, $\mathrm{CuO}$ or FeS in a $\mathrm{Li}_{3} \mathrm{PS}_{4}$ glassy electrolyte $[5,6]$.

Among the three crystal structures of $\alpha, \beta$ and $\gamma$ for $\mathrm{Li}_{3} \mathrm{PS}_{4}$, the $\beta$ phase has been reported to be only stable at temperatures higher than $160{ }^{\circ} \mathrm{C}$ [1]. Owing to its high ionic conductivity, the stabilization of the $\beta$ phase at room temperature has been attracting efforts from researchers for years. One of the first attempts was made by Takada et al., who employed a melt quenching method to freeze this high-temperature phase and made it stable at room temperature [7]. The $\beta$ phase was found to be easily synthesized at room temperature by the reaction between $\mathrm{Li}_{2} \mathrm{~S}$ and $\mathrm{P}_{2} \mathrm{~S}_{5}$ in tetrahydrofuran (THF) [8]. The $\mathrm{Li}_{3} \mathrm{PS}_{4}$ glass-ceramic crystallized from $75 \mathrm{Li}_{2} \mathrm{~S} \cdot 25 \mathrm{P}_{2} \mathrm{~S}_{5}$ glass also showed the structure of the $\beta$ phase $[9,10]$.

The synthesis of $\mathrm{Li}_{3} \mathrm{PS}_{4}$ using liquid-phase synthesis with organic solvents as reaction media has been intensively investigated recently as an alternate chemical route for the preparation of sulfide-based solid electrolytes rather than the conventional solid state reaction [11-16]. In most of the reports, the effect of the solvents on the formation of $\mathrm{Li}_{3} \mathrm{PS}_{4}$ 
was of primary interest [17-21]. Many other types of organic solvents have been reported to be effective in promoting the reaction between $\mathrm{Li}_{2} \mathrm{~S}$ and $\mathrm{P}_{2} \mathrm{~S}_{5}$, including tetrahydrofuran (THF), acetonitrile, ethyl acetate and ethyl propionate (EP). Furthermore, $\mathrm{Li}_{3} \mathrm{PS}_{4}, \mathrm{Li}_{7} \mathrm{P}_{3} \mathrm{~S}_{11}$ and argyrodite-type $\mathrm{Li}_{7-y} \mathrm{PS}_{6-y} \mathrm{X}(\mathrm{X}=\mathrm{Cl}, \mathrm{Br}$ and I) have also been reported to be obtained by the liquid-phase route. The formation of $\mathrm{Li}_{7} \mathrm{P}_{3} \mathrm{~S}_{11}$ was reported to be strongly dependent on the solvent structure. Dimethoxyethane and acetonitrile were the only two solvents that could promote the formation of $\mathrm{Li}_{7} \mathrm{P}_{3} \mathrm{~S}_{11}[22,23]$. The preparation of argyrodite-type solid electrolytes usually requires a two-step process: $\mathrm{Li}_{3} \mathrm{PS}_{4}$ is first prepared by either a solid-state or liquid reaction, which is followed by the use of ethanol to dissolve all the components of the desired solid electrolytes [24-27].

The number of methods to improve the ionic conductivity of solid electrolytes prepared by the liquid-phase synthesis route is very limited; these methods include the addition of $\mathrm{LiX}(\mathrm{X}=\mathrm{Cl}, \mathrm{Br}$ and $\mathrm{I})$ and a thermal treatment procedure in the case of argyroditetype solid electrolytes [28-32]. Doping $\mathrm{Li}_{3} \mathrm{PS}_{4}$ with oxygen $\left(75 \mathrm{Li}_{2} \mathrm{~S} \cdot 23 \mathrm{P}_{2} \mathrm{~S}_{5} \cdot 2 \mathrm{P}_{2} \mathrm{O}_{5}\right)$ resulted in the increase of ionic conductivity at room temperature (RT) from $1.83 \times 10^{-4} \mathrm{Scm}^{-1}$ to $2.53 \times 10^{-4} \mathrm{Scm}^{-1}$ [33]. However, $\mathrm{Li}_{3} \mathrm{PO}_{4}$ has been employed as a common additive to improve the ionic conductivity and electrochemical property of sulfide-based solid electrolytes $[7,34-36]$. In this study, $100 \mathrm{Li}_{3} \mathrm{PS}_{4} \cdot x \mathrm{Li}_{3} \mathrm{PO}_{4}$ solid electrolytes were prepared by liquid-phase synthesis using ethyl propionate (EP). EP was employed in this study since it was suitable for $\mathrm{Li}_{3} \mathrm{PS}_{4}$ and $\mathrm{Li}_{3} \mathrm{PS}_{4}$ - $\mathrm{LiI}$ solid electrolytes preparation [19,30]. Ultravioletvisible (UV-Vis) spectroscopy evidenced the solvation of $\mathrm{P}_{2} \mathrm{~S}_{5}$ but not of $\mathrm{Li}_{3} \mathrm{PO}_{4}$ in EP. The reaction between $\mathrm{P}_{2} \mathrm{~S}_{5}$ and $\mathrm{Li}_{3} \mathrm{PO}_{4}$ in EP was also detected by UV-Vis spectroscopy. Solid phosphorus-31 magic angle spinning nuclear magnetic resonance ( $\left({ }^{31} \mathrm{P}\right.$ MAS NMR) also revealed the formation of $\mathrm{POS}_{3}{ }^{3-}$, which confirmed the results from UV-Vis spectroscopy. An increase in ionic conductivity and decrease in activation energy were achieved by the addition of $\mathrm{Li}_{3} \mathrm{PO}_{4}$. An improvement of the stability against Li metal was also observed using the direct current polarization test. Better charge-discharge capacity of the all-solidstate (ASS) half-cell was also observed employing the sample with $x=6$ compared with that employing the sample with $x=0$.

\section{Materials and Methods}

$\mathrm{Li}_{2} \mathrm{~S}$ (99.9\%, Mitsuwa, Torrance, CA, USA), $\mathrm{P}_{2} \mathrm{~S}_{5}$ (99\%, Merck, Kenilworth, NJ, USA) and $\mathrm{Li}_{3} \mathrm{PO}_{4}$ (99.99\%, Aldrich, St. Louis, MO, USA) were purchased and used without any further treatment process. Super dehydrated ethyl propionate (EP) (99.5\%, Aldrich) was dried again using a 3-Å molecular sieve for at least $24 \mathrm{~h}$ prior to usage. The positive electrode material, $\mathrm{LiNbO}_{3}$-coated $\mathrm{LiNi}_{1 / 3} \mathrm{Mn}_{1 / 3} \mathrm{Co}_{1 / 3} \mathrm{O}_{2}$, was kindly donated by Toda Kogyo.

$\mathrm{Li}_{2} \mathrm{~S}, \mathrm{P}_{2} \mathrm{~S}_{5}, \mathrm{Li}_{3} \mathrm{PO}_{4}$ and $\mathrm{P}_{2} \mathrm{~S}_{5}-\mathrm{Li}_{3} \mathrm{PO}_{4}$ were put into a screw vial followed by the addition of EP. The three bins were sealed in an Ar-filled glovebox and then ultrasonically treated for $30 \mathrm{~min}$. The as-prepared samples were then filtered for UV-Vis measurement.

$100 \mathrm{Li}_{3} \mathrm{PS}_{4} \cdot x \mathrm{Li}_{3} \mathrm{PO}_{4}$ solid electrolytes in this study were prepared from raw materials using the liquid-phase shaking method that has previously been reported [19]. $\mathrm{Li}_{2} \mathrm{~S}$, $\mathrm{P}_{2} \mathrm{~S}_{5}$ and $\mathrm{Li}_{3} \mathrm{PO}_{4}$ to form $1 \mathrm{~g}$ of $100 \mathrm{Li}_{3} \mathrm{PS}_{4}-\chi \mathrm{Li}_{3} \mathrm{PO}_{4}$ were weighted and put into a plastic centrifuge tube together with zirconia balls ( $4 \mathrm{~mm}, 150$ balls). The tube was filled with $20 \mathrm{~mL}$ of EP and then shaken at $1500 \mathrm{rpm}$ for $6 \mathrm{~h}$ with amplitude of $1 \mathrm{~cm}$. The received suspension was centrifuged and decanted to receive the precipitated pastes. The thus obtained samples were then dried under vacuum at room temperature and heat treated at $170{ }^{\circ} \mathrm{C}$ for $2 \mathrm{~h}$.

The crystal structures of the samples were examined by X-ray diffraction (XRD; Ultima IV, Rigaku, Tokyo, Japan) using an air-tight holder to protect the samples from air humidity. Local structure of the prepared solid electrolytes was investigated by solid-state ${ }^{31} \mathrm{P}$ MAS NMR spectroscopy (Avance III 400, Bruker, Tokyo, Japan) using the typical single pulse sequence with a spinning rate of $5 \mathrm{kHz}$. UV-Vis spectra were recorded using a V-670 spectrophotometer (Jasco, Tokyo, Japan). 
Alternating-current impedance spectroscopy (SI 1260, Solartron, Tokyo, Japan) was employed to measure the temperature dependence of the total conductivity of the prepared samples. Powder samples were placed in an PEEK holder $(10 \mathrm{~mm}$ in diameter) with two SUS electrodes (Misumi) then pressed at $550 \mathrm{MPa}$ (RT). The cell was placed under an Ar stream in a glass tube to measure the temperature dependence of resistivity. The temperature was gradually increased from room temperature to $210^{\circ} \mathrm{C}$ and held at each temperature for $1 \mathrm{~h}$ prior to the impedance measurement.

The pelletized sample (diameter of $10 \mathrm{~mm}$ ) with lithium metal sheets attached on both sides to serve as nonblocking electrodes were made to study the stability of solid electrolytes against lithium metal by DC polarization examination. Current collectors were Au-sputtered SUS rods. The cells were then cycled at $\pm 0.05 \mathrm{~mA} \mathrm{~cm}^{-2}$ under a dry Ar atmosphere using a charge-discharge device (NAGANO BST-2004H, Nagano, Japan).

An ASS half-cell was fabricated to investigate the electrochemical performance of the prepared solid electrolytes (SE). The prepared SE was employed as a separator and an In- $\mathrm{Li}$ alloy was used as the negative electrode. The positive electrode composites (PE) composed of $\mathrm{LiNbO}_{3}$-coated $\mathrm{LiNi}_{1 / 3} \mathrm{Mn}_{1 / 3} \mathrm{Co}_{1 / 3} \mathrm{O}_{2}$ (NMC), solid electrolytes and acetylene black (weight ratio of 70:30:3) were prepared using agate mortar and pestle. The bilayer pellets $(\phi 10 \mathrm{~mm})$, composed of PE and separator layers $(80 \mathrm{mg})$, were prepared by uniaxial pressing at $550 \mathrm{MPa}$. Indium foil was then attached onto the pellets by pressing at $200 \mathrm{MPa}$. The loading of PE in each cell was about $15 \mathrm{mg}$, in according to loading of NMC of 11-13 mg. Two stainless steel rods served as current collectors. Cyclic voltammetry (at RT) at a scan rate of $0.1 \mathrm{mV} \mathrm{s}^{-1}$ (SI1287 potentiostat, Solartron, Tokyo, Japan) was employed to study the electrochemical compatibility of the obtained SEs. The cells were cycled using a charge-discharge device (NAGANO BST-2004H, Nagano, Japan) in a dry Ar atmosphere. The cutoff voltages were in the range of 3.7-2.0 V vs. Li-In at $0.1 \mathrm{C}$. All the cells were placed in an insulation box that was kept at $30 \pm 2{ }^{\circ} \mathrm{C}$ for $4 \mathrm{~h}$ prior to being tested. Cell preparation was conducted inside an Ar-filled glove-box with $\mathrm{O}_{2} \leq 1.0 \mathrm{ppm}$ and $\mathrm{H}_{2} \mathrm{O} \leq 0.1 \mathrm{ppm}$.

\section{Results}

Figure 1 shows the optical images of the $\mathrm{Li}_{2} \mathrm{~S}, \mathrm{Li}_{3} \mathrm{PO}_{4}, \mathrm{P}_{2} \mathrm{~S}_{5}$ and $\mathrm{Li}_{3} \mathrm{PO}_{4}-\mathrm{P}_{2} \mathrm{~S}_{5}$ solutions in EP solvent and UV-Vis spectra of the $\mathrm{Li}_{3} \mathrm{PO}_{4}, \mathrm{P}_{2} \mathrm{~S}_{5}$ and $\mathrm{Li}_{3} \mathrm{PO}_{4}-\mathrm{P}_{2} \mathrm{~S}_{5}$ solutions in EP solvent. The spectrum of the $\mathrm{Li}_{3} \mathrm{PO}_{4}$ solution exhibited no absorbance peak in the measurement range from 190 to $1200 \mathrm{~nm}$. This result illustrated that $\mathrm{Li}_{3} \mathrm{PO}_{4}$ was unable to be dissolved in the EP solvent. The $\mathrm{P}_{2} \mathrm{~S}_{5}$ solution had one sharp peak centered at approximately $264 \mathrm{~nm}$, which indicated the dissolution of $\mathrm{P}_{2} \mathrm{~S}_{5}$ in EP. The spectrum of $\mathrm{Li}_{3} \mathrm{PO}_{4}-\mathrm{P}_{2} \mathrm{~S}_{5}$ in EP exhibited a large shoulder shape that was then deconvoluted into three other peaks centered at 264, 280 and $359 \mathrm{~nm}$ (small inset in Figure 1). The peak at $264 \mathrm{~nm}$ indicated the existence of $\mathrm{P}_{2} \mathrm{~S}_{5}$ in the solution. The other two peaks originated from neither $\mathrm{Li}_{3} \mathrm{PO}_{4}$ nor $\mathrm{P}_{2} \mathrm{~S}_{5}$, so they were proposed to arise from the products of the reaction between $\mathrm{P}_{2} \mathrm{~S}_{5}$ and $\mathrm{Li}_{3} \mathrm{PO}_{4}$. The UV-Vis spectra proved that $\mathrm{P}_{2} \mathrm{~S}_{5}$ dissolution in EP was the initial step for the reaction with $\mathrm{Li}_{3} \mathrm{PO}_{4}$ in EP solvent. To the best of our knowledge, this is the first time that such a reaction has been reported and evidenced using simple UV-Vis spectroscopy. 

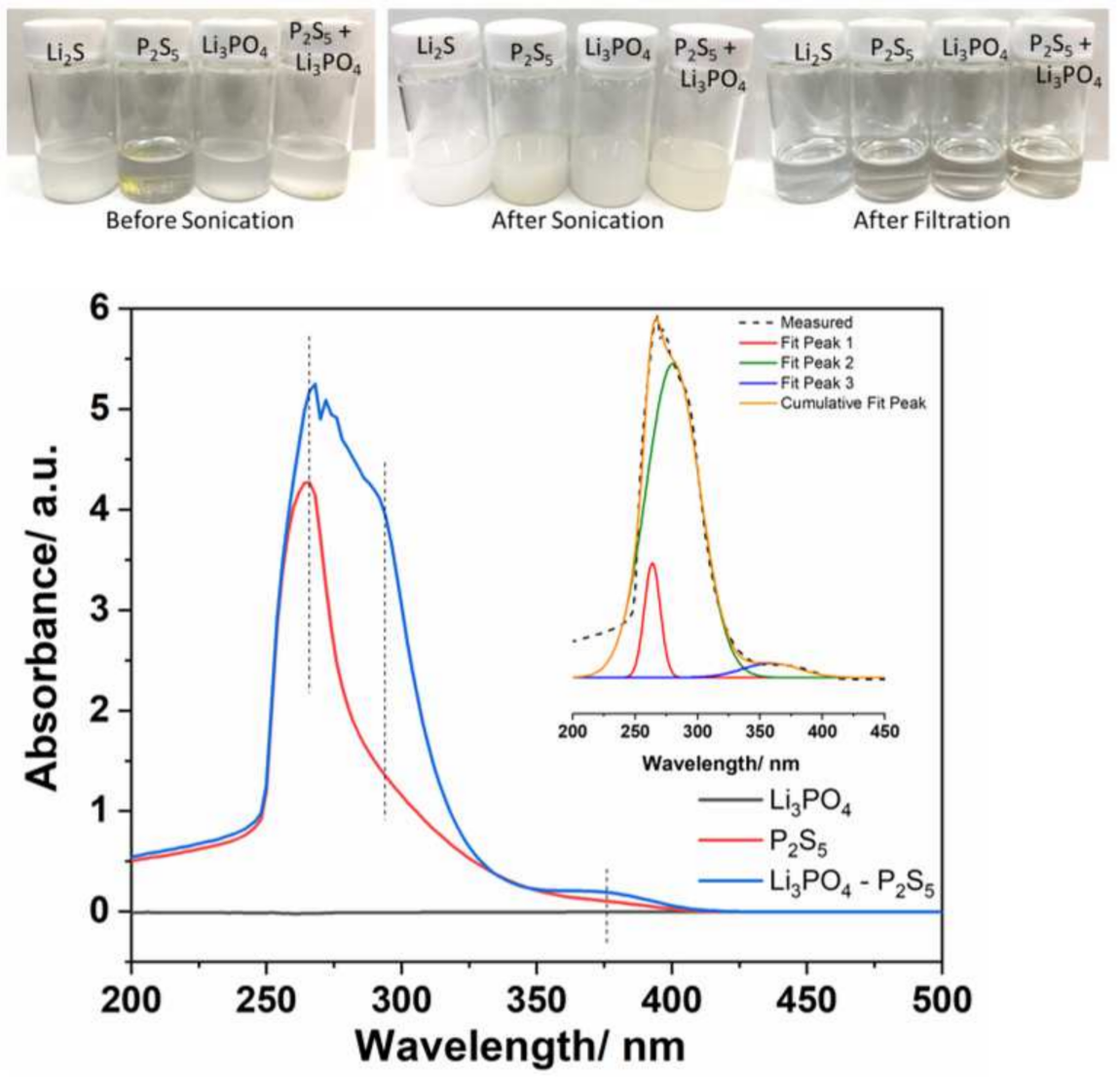

Figure 1. Optical photographs and UV-Vis spectra of $\mathrm{Li}_{3} \mathrm{PO}_{4}, \mathrm{P}_{2} \mathrm{~S}_{5}$ and $\mathrm{Li}_{3} \mathrm{PO}_{4}-\mathrm{P}_{2} \mathrm{~S}_{5}$ in EP solutions.

Figure 2 shows the XRD patterns of $100 \mathrm{Li}_{3} \mathrm{PS}_{4} \cdot x \mathrm{Li}_{3} \mathrm{PO}_{4}$ obtained after solvent elimination at room temperature (Figure 2a) and at $170{ }^{\circ} \mathrm{C}$ for $2 \mathrm{~h}$ (Figure $2 \mathrm{~b}$ ). The powder samples obtained at room temperature exhibited similar XRD patterns without any peak from the starting materials with a value of $x$ of up to 20. The pattern resembled that of a cocrystal of $\mathrm{Li}_{3} \mathrm{PS}_{4}$ and $\mathrm{EP}$ that has been reported previously [19]. After solvent elimination at $170{ }^{\circ} \mathrm{C}$, the $\mathrm{XRD}$ patterns of the retrieved samples exhibited the feature of $\beta-\mathrm{Li}_{3} \mathrm{PS}_{4}$, and signals of $\mathrm{Li}_{3} \mathrm{PO}_{4}(\mathrm{LPO})$ were also detected for the sample with $x=20[8,18]$. The XRD results proved that $\mathrm{Li}_{3} \mathrm{PO}_{4}$ could be incorporated into $\mathrm{Li}_{3} \mathrm{PS}_{4}$ up to at least $6 \mathrm{~mol} \%$ by the proposed liquid-phase synthesis. As mentioned above, a solid solution between $\mathrm{Li}_{3} \mathrm{PS}_{4}$ and $\mathrm{Li}_{3} \mathrm{PO}_{4}$ was successfully prepared by the melt quenching method with $x$ up to 50 but the structure of $\mathrm{Li}_{3} \mathrm{PS}_{4}$ was changed upon interaction with $\mathrm{Li}_{3} \mathrm{PO}_{4}$ [7]. $\mathrm{Li}_{3} \mathrm{PO}_{4}$ was doped into $0.6 \mathrm{Li}_{2} \mathrm{~S} \cdot 0.4 \mathrm{SiS}_{2}$ glass and glass-ceramic. It was observed that the $0.6 \mathrm{Li}_{2} \mathrm{~S} \cdot 0.4 \mathrm{SiS}_{2}$ glass could dissolve $20 \mathrm{~mol} \%$ of $\mathrm{Li}_{3} \mathrm{PO}_{4}$ but its crystal structure was detected by XRD in the $0.6 \mathrm{Li}_{2} \mathrm{~S} \cdot 0.4 \mathrm{SiS}_{2}$ glass-ceramic [37]. $\mathrm{Li}_{3} \mathrm{PO}_{4}$ was also doped into the $70 \mathrm{Li}_{2} \mathrm{~S} \cdot 30 \mathrm{P}_{2} \mathrm{~S}_{5}$ glass-ceramic and was found to change the crystal structure from $\mathrm{Li}_{7} \mathrm{P}_{3} \mathrm{~S}_{11}$ to thio-LISICON II with only $5 \mathrm{~mol} \%$ of dopant [38]. 


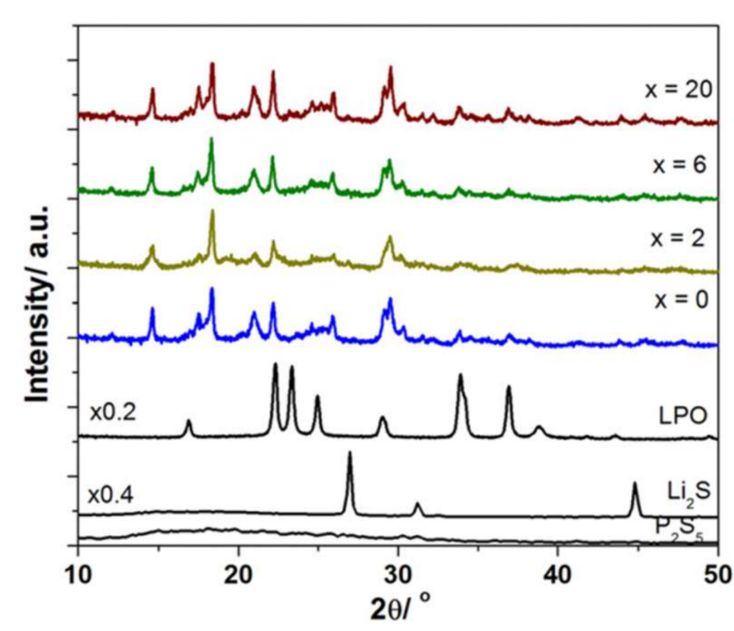

(a)

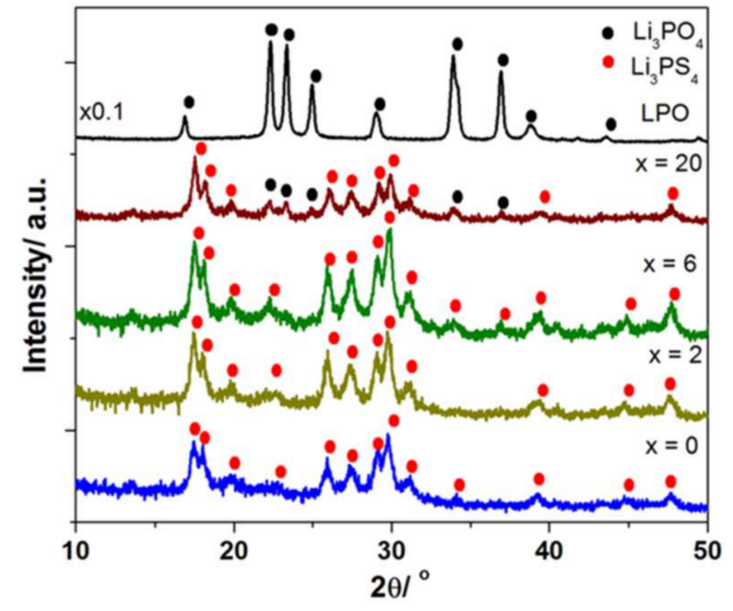

(b)

Figure 2. XRD patterns of $100 \mathrm{Li}_{3} \mathrm{PS}_{4}-\mathrm{xLi} 3 \mathrm{PO}_{4}$ samples dried at room temperature (RT) (a) and $170{ }^{\circ} \mathrm{C}(\mathbf{b})$.

Figure 3 shows the solid ${ }^{31} \mathrm{P}$ MAS NMR results of $\mathrm{Li}_{3} \mathrm{PO}_{4}$ and the samples with $x=0$ and 6 (Figure 3a) and their deconvolution results (Figure $3 \mathrm{~b}, \mathrm{c}$ ). The sample with $x=6$ had a small peak located at $8.0 \mathrm{ppm}$ that indicated the existence of $\mathrm{Li}_{3} \mathrm{PO}_{4}$, which resembled that of pristine $\mathrm{Li}_{3} \mathrm{PO}_{4}$. The large shoulder observed for the sample with $x=0$ was composed of three other peaks located at $81.5,83.6$ and $85.7 \mathrm{ppm}$ (Figure $3 \mathrm{~b}$ ). The peak located at $81.5 \mathrm{ppm}$ was assigned to amorphous $\mathrm{PS}_{4}{ }^{3-}[39,40]$. The peaks at 83.6 and 85.7 were from $\mathrm{PS}_{4}{ }^{3-}$ in $\beta$ - and $\gamma$-Li $3 \mathrm{PS}_{4}$, respectively [40]. Surprisingly, the area fraction of the amorphous phase was the highest, approximately $78 \%$, while that of the $\beta$ phase was just $15 \%$. The main peak in the NMR spectrum of the sample with $x=6$ was also decomposed into three peaks located at $82.4,83.5$ and $85.8 \mathrm{ppm}$ (Figure 3c). The peaks at 82.4 and 85.8 originated from amorphous and crystal $\mathrm{PS}_{4}{ }^{3-}$. The peak at $83.5 \mathrm{ppm}$ arose from both $\mathrm{PS}_{4}{ }^{3-}$ and $\mathrm{POS}_{3}{ }^{3-}$ ions [37]. In addition, the area fraction of the amorphous peak for the sample with $x=6$ was $62 \%$ and that of the peak at $83.5 \mathrm{ppm}$ was $32 \%$. These values showed the reverse trend to that observed for the sample with $x=0$ but the area fraction of $\mathrm{PS}_{4}{ }^{3-}$ from $\gamma-\mathrm{Li}_{3} \mathrm{PS}_{4}$ was almost unchanged. These results proved the formation of a $\mathrm{POS}_{3}{ }^{3-}$ ion and thus evidenced the reaction between $\mathrm{P}_{2} \mathrm{~S}_{5}$ and $\mathrm{Li}_{3} \mathrm{PO}_{4}$ in an EP medium. The area fraction of the amorphous phase in the NMR spectra was surprisingly high in this study, which might be the reason for the low intensity of the XRD peak shown in Figure 2b.

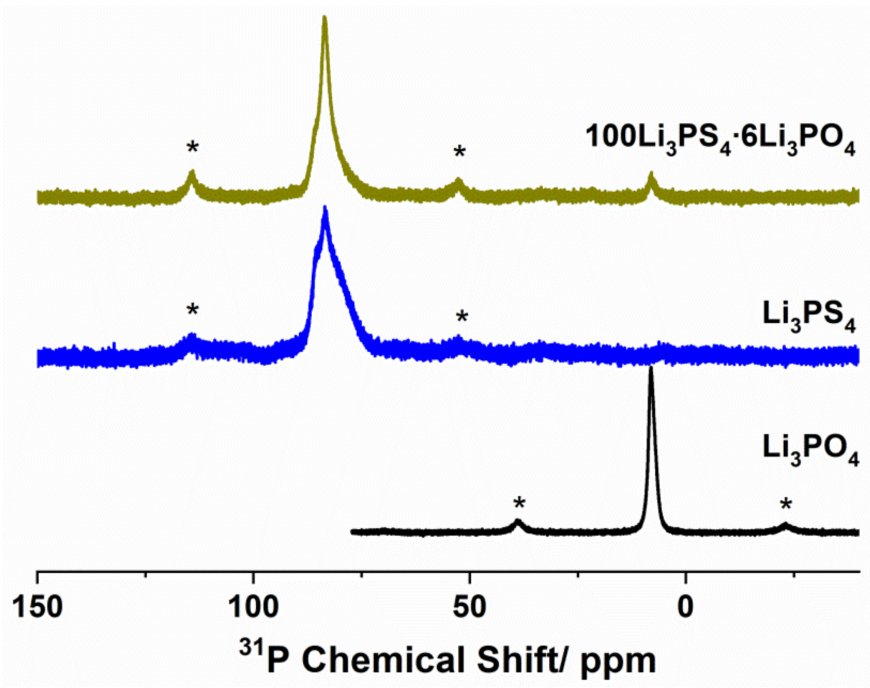

(a)

Figure 3. Cont. 


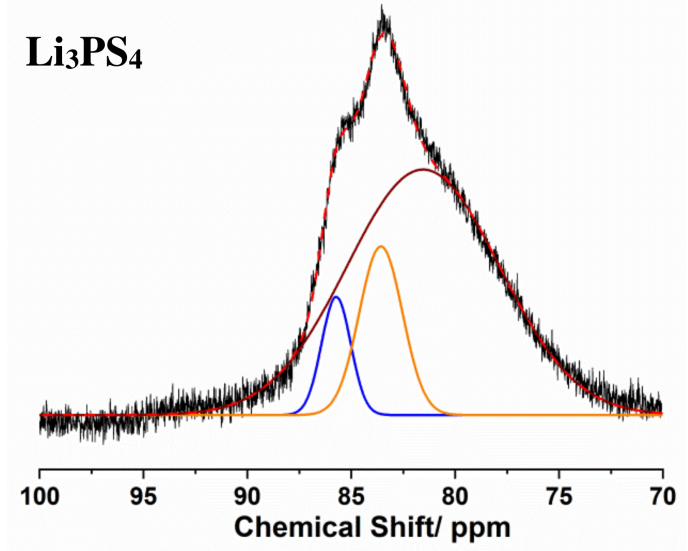

(b)

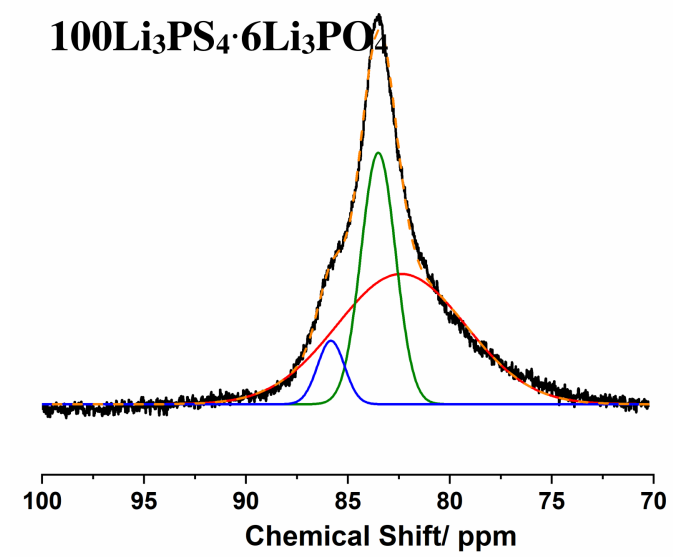

(c)

Figure 3. ${ }^{31} \mathrm{P}$ Solid MAS NMR spectra of $\mathrm{Li}_{3} \mathrm{PO}_{4}, \mathrm{Li}_{3} \mathrm{PS}_{4}$ and $100 \mathrm{Li}_{3} \mathrm{PS}_{4} \cdot 6 \mathrm{Li}_{3} \mathrm{PO}_{4}(\mathbf{a})$, the asterik * indicated the spinning side bands; deconvolution of main peak of $\mathrm{Li}_{3} \mathrm{PS}_{4}(\mathbf{b})$; deconvolution of main peak of $100 \mathrm{Li}_{3} \mathrm{PS}_{4} \cdot 6 \mathrm{Li}_{3} \mathrm{PO}_{4}(\mathbf{c})$.

Figure 4 shows the temperature dependence of the ionic conductivity (Figure 4a) and conductivity at room temperature and activation energy as a function of $x$ (Figure $4 \mathrm{~b}$ ) for $100 \mathrm{Li}_{3} \mathrm{PS}_{4} \cdot x \mathrm{Li}_{3} \mathrm{PO}_{4}$. The temperature dependence of the ionic conductivity showed that at a temperature higher than $60^{\circ} \mathrm{C}$, the sample with $x=0$ exhibited the highest ionic conductivity but below this temperature, the sample with $x=6$ had the highest ionic conductivity. Conductivity at room temperature and activation energy as a function of $x$ showed that upon addition of $\mathrm{Li}_{3} \mathrm{PO}_{4}$, the ionic conductivity started to increase and reached the highest value at $x=6$. The activation energy showed the reverse trend with the ionic conductivity and reached the lowest value at $x=6$. For the samples with $x=0$ and 6 , conductivity at room temperature was $1.9 \times 10^{-4}$ and $3.3 \times 10^{-4} \mathrm{Scm}^{-1}$, respectively, and activation energy was 42 and $27 \mathrm{~kJ} \mathrm{~mol}^{-1}$, respectively. At $x$ values higher than 6 , the ionic conductivity started to reduce together with the increase in activation energy due to the remaining of $\mathrm{Li}_{3} \mathrm{PO}_{4}$ in the samples. The ionic conductivity of the samples obtained in this study was higher than the reported values of $\mathrm{Li}_{3} \mathrm{PS}_{4}-\mathrm{Li}_{3} \mathrm{PO}_{4}$ prepared by melt-quenching method but lower than the glass-ceramic samples [7,41]. Li ion movement changing from $2 \mathrm{D}$ to $3 \mathrm{D}$ with oxygen doping was the main reason for improvement in both ionic conductivity and activation energy of $\beta-\mathrm{Li}_{3} \mathrm{PS}_{4}$ as shown by Wang et al. in their DFT calculation study [42]. Oxygen doping in both glass and glass-ceramic $\mathrm{Li}_{3} \mathrm{PS}_{4}$ solid electrolytes was found to be an effective method to boot their ionic conductivity by using either $\mathrm{Li}_{2} \mathrm{O}$ or $\mathrm{P}_{2} \mathrm{O}_{5}$ as oxygen sources $[41,43]$.

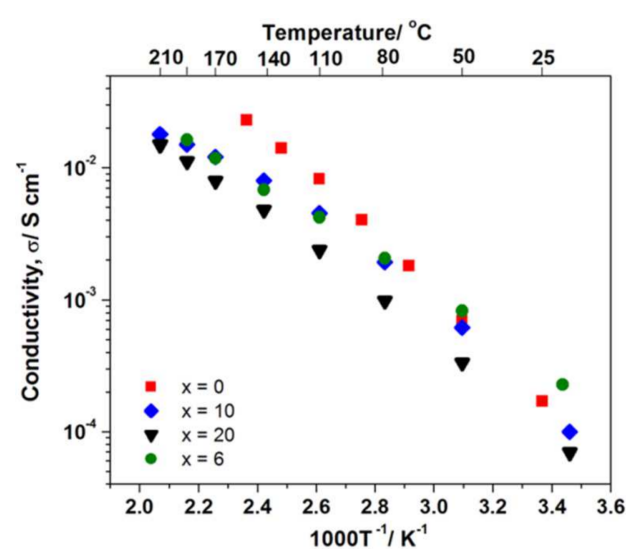

(a)

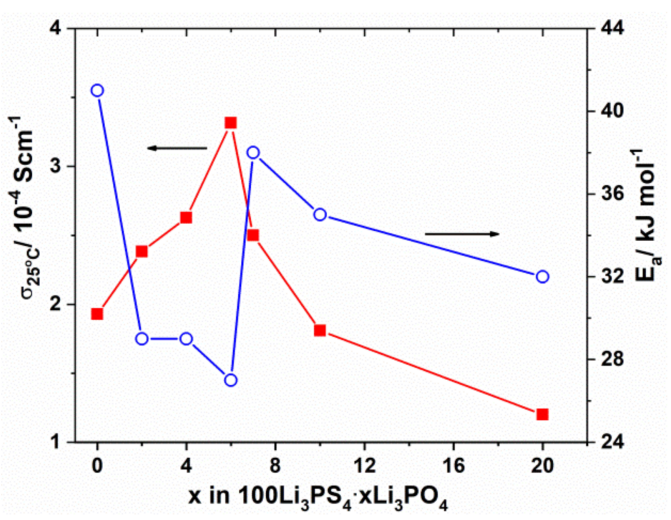

(b)

Figure 4. Temperature dependence of conductivity of $100 \mathrm{Li}_{3} \mathrm{PS}_{4} \cdot x \mathrm{Li}_{3} \mathrm{PO}_{4}$ samples dried at $170{ }^{\circ} \mathrm{C}$; (a) room temperature ionic conductivity and (b) activation energy as a function of composition. 
Two symmetric cells, $\mathrm{Li}\left|\mathrm{Li}_{3} \mathrm{PS}_{4}\right| \mathrm{Li}$ and $\mathrm{Li}\left|100 \mathrm{Li}_{3} \mathrm{PS}_{4} \cdot 6 \mathrm{Li}_{3} \mathrm{PO}_{4}\right| \mathrm{Li}$, were constructed to investigate the stability of the samples with $x=0$ and 6 against Li metal using the direct current polarization test. The results are illustrated in Figure 5a. The $\mathrm{Li}\left|\mathrm{Li}_{3} \mathrm{PS}_{4}\right| \mathrm{Li}$ cell had an initial voltage of approximately $32 \mathrm{mV}$ while that of the $\mathrm{Li}\left|100 \mathrm{Li}_{3} \mathrm{PS}_{4} \cdot 6 \mathrm{Li}_{3} \mathrm{PO}_{4}\right| \mathrm{Li}$ cell was approximately $18 \mathrm{mV}$ because of the smaller resistivity. The $\mathrm{Li}\left|\mathrm{Li}_{3} \mathrm{PS}_{4}\right| \mathrm{Li}$ cell exhibited a slight change of its voltage to approximately $35 \mathrm{mV}$ after $100 \mathrm{~h}$ in the test condition. In contrast, the $\mathrm{Li}\left|100 \mathrm{Li}_{3} \mathrm{PS}_{4} \cdot 6 \mathrm{Li}_{3} \mathrm{PO}_{4}\right| \mathrm{Li}$ cell exhibited a voltage profile that was nearly constant after $200 \mathrm{~h}$ in the working condition. These results proved that the addition of $\mathrm{Li}_{3} \mathrm{PO}_{4}$ was able to improve the stability of sulfide-based solid electrolytes against metallic Li. A similar enhancement of the stability against metallic Li was obtained when $\beta-\mathrm{Li}_{3} \mathrm{PS}_{4}$ was doped with $\mathrm{Sb}_{2} \mathrm{O}_{5}$ [44]. The improvement of the stability against metallic Li was explained by the formation of an interfacial buffer layer from the reaction between solid electrolytes and metallic $\mathrm{Li}$ [45].

$\mathrm{LiNbO}_{3}$-coated $\mathrm{LiNi}_{1 / 3} \mathrm{Mn}_{1 / 3} \mathrm{Co}_{1 / 3} \mathrm{O}_{2}$ instead of bare $\mathrm{LiNi}_{1 / 3} \mathrm{Mn}_{1 / 3} \mathrm{Co}_{1 / 3} \mathrm{O}_{2}$ was employed to reduce the side reaction occurring at the solid electrolyte and active material interface [45]. The initial charge capacities of both cells using the samples with $x=0$ and $x=6$ were $170 \mathrm{mAh}^{-1} \mathrm{NMC}$, respectively, and the discharge capacities were 148 and $150 \mathrm{mAh} \mathrm{g}^{-1} \mathrm{NMC}$, respectively. From the second cycle, the discharge capacity of the cell for the sample with $x=6$ increased to $158 \mathrm{mAh} \mathrm{g}^{-1} \mathrm{NMC}$ whereas that of the sample with $x=0$ reduced to $146 \mathrm{mAh}^{-1} \mathrm{NMC}$. The superior discharge capacity of the cell employing the sample with $x=6$, compared with that of the cell employing the sample with $x=0$, remained for the investigated 20 cycles. These results proved that doping $\mathrm{Li}_{3} \mathrm{PS}_{4}$ with $6 \mathrm{~mol} \% \mathrm{Li}_{3} \mathrm{PO}_{4}$ improved the cell performance compared with the intrinsic electrolyte sample.
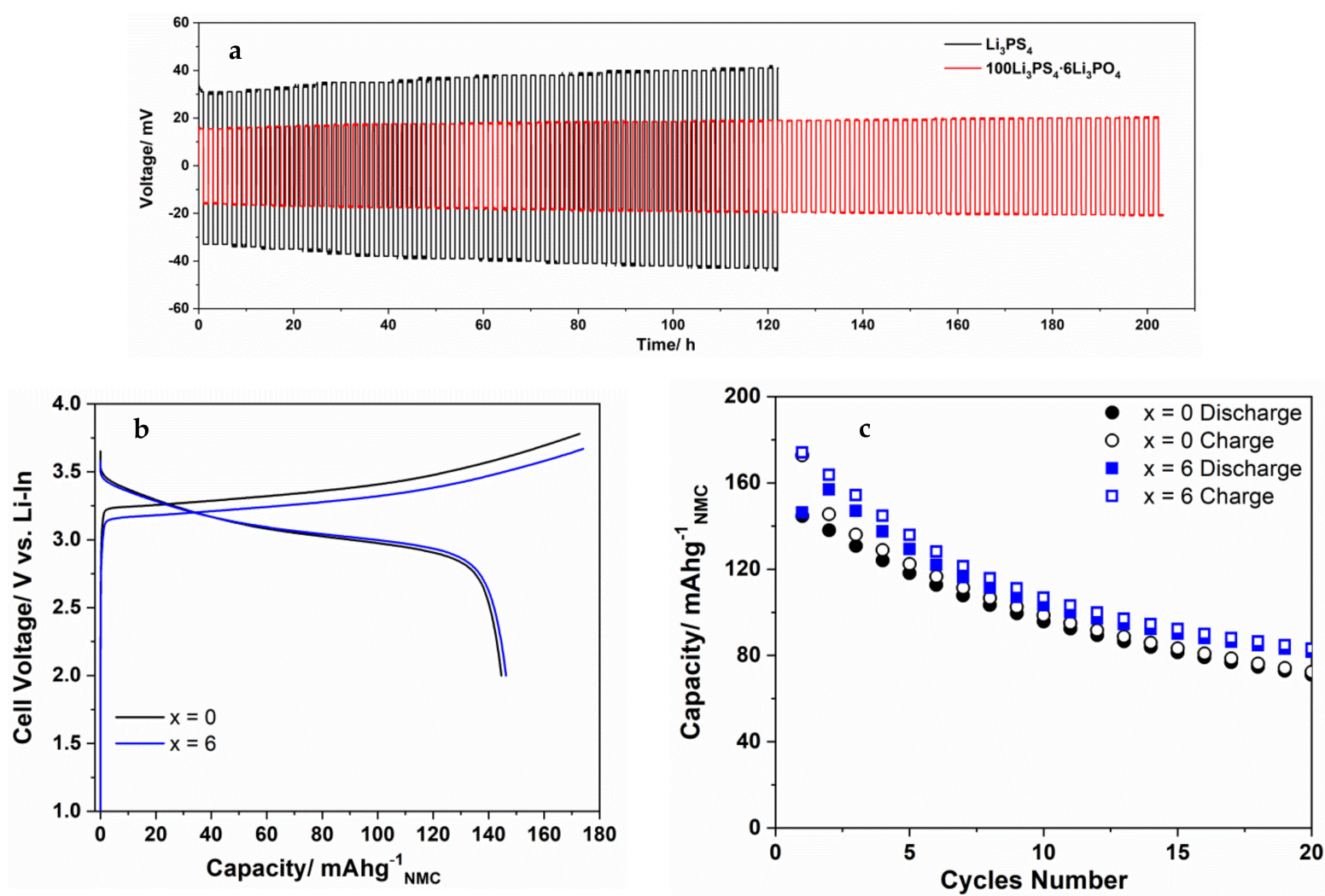

Figure 5. DC polarization of Li I LPSO I Li cell at $0.05 \mathrm{~mA} \mathrm{~cm}^{-2}$ (a); first charge-discharge curves and cyclic properties of all-solid-state cells employing either sample with $x=0$ or 6 as solid electrolytes at the positive electrodes (b); cyclic performance of all-solid-state half-cells employing samples with $x=0$ and $x=6$ at the positive electrodes (c). 


\section{Conclusions}

$100 \mathrm{Li}_{3} \mathrm{PS}_{4} \cdot x \mathrm{Li}_{3} \mathrm{PO}_{4}$ solid electrolytes were successfully prepared by the liquid-phase shaking method using EP as the reaction medium. The reaction between $\mathrm{Li}_{3} \mathrm{PO}_{4}$ and $\mathrm{P}_{2} \mathrm{~S}_{5}$ was evidenced by UV-Vis spectroscopy, where the dissolution of $\mathrm{P}_{2} \mathrm{~S}_{5}$ in EP was the initial step of the activation of $\mathrm{Li}_{3} \mathrm{PO}_{4}$. The formation of the $\mathrm{POS}_{3}{ }^{3-}$ ion was further proved by solid ${ }^{31} \mathrm{P}$ MAS NMR. It was observed that the incorporation of $\mathrm{Li}_{3} \mathrm{PO}_{4}$ into $\mathrm{Li}_{3} \mathrm{PS}_{4}$ could improve not only the ionic conductivity and activation energy but also stability against metallic Li. The charge-discharge capacities of the all-solid-state cell employing the $100 \mathrm{Li}_{3} \mathrm{PS}_{4} \cdot 6 \mathrm{Li}_{3} \mathrm{PO}_{4}$ solid electrolyte at the positive electrode was slightly higher than those of the cell using $\mathrm{Li}_{3} \mathrm{PS}_{4}$ in the positive electrode.

Author Contributions: Conceptualization, methodology, software, validation, formal analysis, N.H.H.P.; investigation, N.H.H.P., T.M. and T.Y.; writing—original draft preparation, N.H.H.P.; writing—-review and editing, N.H.H.P. and A.M.; supervision, A.M. and H.M.; project administration, A.M. and H.M.; funding acquisition, A.M. and H.M. All authors have read and agreed to the published version of the manuscript.

Funding: This study was supported by the Advanced Low Carbon Technology Specially Promoted Research for Innovative Next Generation Batteries (JST-ALCA-SPRING, Grant No. JPMJAL1301) program of the Japan Science and Technology Agency.

Institutional Review Board Statement: Not applicable.

Informed Consent Statement: Not applicable.

Data Availability Statement: The data presented in this study are available on request from the corresponding authors.

Acknowledgments: The authors appreciate R. Kato of the Cooperative Research Facility Center, Toyohashi University of Technology for his assistance in NMR measurement. We thank Edanz Group (https:/ / en-author-services.edanzgroup.com/ac) for editing a draft of this manuscript.

Conflicts of Interest: The authors declare no conflict of interest. The funders had no role in the design of the study; in the collection, analyses, or interpretation of the data; in the writing of the manuscript, or in the decision to publish the results.

\section{References}

1. Homma, K.; Yonemura, M.; Kobayashi, T.; Nagao, M.; Hirayama, M.; Kanno, R. Crystal structure and phase transitions of the lithium ionic conductor $\mathrm{Li}_{3} \mathrm{PS}_{4}$. Solid State Ion. 2011, 182, 53-58. [CrossRef]

2. Muramatsu, H.; Hayashi, A.; Ohtomo, T.; Hama, S.; Tatsumisago, M. Tatsumisago, Structural change of $\mathrm{Li}_{2} \mathrm{~S}-\mathrm{P}_{2} \mathrm{~S}_{5}$ sulfide solid electrolytes in the atmosphere. Solid State Ion. 2011, 182, 116-119. [CrossRef]

3. Feng, X.; Chien, P.-H.; Patel, S.; Zheng, J.; Immediato-Scuotto, M.; Xin, Y.; Hung, I.; Gan, Z.; Hu, Y.-Y. Synthesis and characterizations of highly conductive and stable electrolyte $\mathrm{Li}_{10} \mathrm{P}_{3} \mathrm{~S}_{12} \mathrm{I}$. Energy Storage Mater. 2019, 22, 397-401. [CrossRef]

4. Spannenberger, S.; Miß, V.; Klotz, E.; Kettner, J.; Cronau, M.; Ramanayagam, A.; Di Capua, F.; Elsayed, M.; Krause-Rehberg, R.; Vogel, M.; et al. Annealing-induced vacancy formation enables extraordinarily high Li+ ion conductivity in the amorphous electrolyte 0.33LiI + 0.67Li $\mathrm{PS}_{4}$. Solid State Ion. 2019, 341. [CrossRef]

5. Ohtomo, T.; Hayashi, A.; Tatsumisago, M.; Kawamoto, K. Suppression of $\mathrm{H}_{2} \mathrm{~S}$ gas generation from the $75 \mathrm{Li}_{2} \mathrm{~S}^{2} 25 \mathrm{P}_{2} \mathrm{~S}_{5}$ glass electrolyte by additives. J. Mater. Sci. 2013, 48, 4137-4142. [CrossRef]

6. Calpa, M.; Rosero-Navarro, N.C.; Miura, A.; Jalem, R.; Tateyama, Y.; Tadanaga, K. Chemical stability of $\mathrm{Li}_{4} \mathrm{PS}_{4} \mathrm{I}$ solid electrolyte against hydrolysis. Appl. Mater. Today 2021, 22, 100918.

7. Takada, K.; Osada, M.; Ohta, N.; Inada, T.; Kajiyama, A.; Sasaki, H.; Kondo, S.; Watanabe, M.; Sasaki, T. Lithium ion conductive oxysulfide, $\mathrm{Li}_{3} \mathrm{PO}_{4}-\mathrm{Li}_{3} \mathrm{PS}_{4}$. Solid State Ion. 2005, 176, 2355-2359. [CrossRef]

8. Liu, Z.; Fu, W.; Payzant, E.A.; Yu, X.; Wu, Z.; Dudney, N.J.; Kiggans, J.; Hong, K.; Rondinone, A.J.; Liang, C. Anomalous high ionic conductivity of nanoporous beta-Li $\mathrm{PS}_{4}$. J. Am. Chem. Soc. 2013, 135, 975-978. [CrossRef] [PubMed]

9. Tsukasaki, H.; Mori, S.; Morimoto, H.; Hayashi, A.; Tatsumisago, M. Direct observation of a non-crystalline state of $\mathrm{Li}_{2} \mathrm{~S}_{-} \mathrm{P}_{2} \mathrm{~S}_{5}$ solid electrolytes. Sci. Rep. 2017, 7, 1-7. [CrossRef]

10. Tsukasaki, H.; Mori, S.; Shiotani, S.; Yamamura, H. Yamamura, Ionic conductivity and crystallization process in the $\mathrm{Li}_{2} \mathrm{~S}_{-} \mathrm{P}_{2} \mathrm{~S}_{5}$ glass electrolyte. Solid State Ion. 2018, 317, 122-126. [CrossRef]

11. Ohara, K.; Masuda, N.; Yamaguchi, H.; Yao, A.; Tominaka, S.; Yamada, H.; Hiroi, S.; Takahashi, M.; Yamamoto, K.; Wakihara, T.; et al. Observation of Liquid Phase Synthesis of Sulfide Solid Electrolytes Using Time-Resolved Pair Distribution Function Analysis. Phys. Status Solidi 2020, 257, 2000106. [CrossRef] 
12. Yamamoto, K.; Takahashi, M.; Ohara, K.; Phuc, N.H.H.; Yang, S.; Watanabe, T.; Uchiyama, T.; Sakuda, A.; Hayashi, A.; Tatsumisago, M.; et al. Synthesis of Sulfide Solid Electrolytes through the Liquid Phase: Optimization of the Preparation Conditions. ACS Omega 2020, 5, 26287-26294. [CrossRef]

13. Takahashi, M.; Yang, S.; Yamamoto, K.; Ohara, K.; Phuc, N.H.H.; Watanabe, T.; Uchiyama, T.; Sakuda, A.; Hayashi, A.; Tatsumisago, M.; et al. Improvement of lithium ionic conductivity of $\mathrm{Li}_{3} \mathrm{PS}_{4}$ through suppression of crystallization using low-boiling-point solvent in liquid-phase synthesis. Solid State Ion. 2021, 361, 115568. [CrossRef]

14. Calpa, M.; Rosero-Navarro, N.C.; Miura, A.; Terai, K.; Utsuno, F.; Tadanaga, K. Tadanaga, Formation Mechanism of Thiophosphate Anions in the Liquid-Phase Synthesis of Sulfide Solid Electrolytes Using Polar Aprotic Solvents. Chem. Mater. 2020, 32, 9627-9632. [CrossRef]

15. Ghidiu, M.; Schlem, R.; Zeier, W.G. Pyridine Complexes as Tailored Precursors for Rapid Synthesis of Thiophosphate Superionic Conductors. Batter. Supercaps 2020. [CrossRef]

16. Maniwa, R.; Calpa, M.; Rosero-Navarro, N.C.; Miura, A.; Tadanaga, K. Synthesis of sulfide solid electrolytes from $\mathrm{Li}_{2} \mathrm{~S}_{\text {and }} \mathrm{P}_{2} \mathrm{~S}_{5}$ in anisole. J. Mater. Chem. A 2021, 9, 400-405. [CrossRef]

17. Phuc, N.H.H.; Morikawa, K.; Totani, M.; Muto, H.; Matsuda, A. Chemical synthesis of $\mathrm{Li}_{3} \mathrm{PS}_{4}$ precursor suspension by liquidphase shaking. Solid State Ion. 2016, 285, 2-5. [CrossRef]

18. Phuc, N.H.H.; Totani, M.; Morikawa, K.; Muto, H.; Matsuda, A. Preparation of $\mathrm{Li}_{3} \mathrm{PS}_{4}$ solid electrolyte using ethyl acetate as synthetic medium. Solid State Ion. 2016, 288, 240-243. [CrossRef]

19. Phuc, N.H.H.; Morikawa, K.; Mitsuhiro, T.; Muto, H.; Matsuda, A. Synthesis of plate-like $\mathrm{Li}_{3} \mathrm{PS}_{4}$ solid electrolyte via liquid-phase shaking for all-solid-state lithium batteries. Ionics 2017, 23, 2061-2067. [CrossRef]

20. Phuc, N.H.H.; Muto, H.; Matsuda, A. Fast preparation of $\mathrm{Li}_{3} \mathrm{PS}_{4}$ solid electrolyte using methyl propionate as synthesis medium. Mater. Today Proc. 2019, 16, 216-219. [CrossRef]

21. Wang, H.; Hood, Z.D.; Xia, Y.; Liang, C. Fabrication of ultrathin solid electrolyte membranes of $\beta$-Li $\mathrm{PS}_{4}$ nanoflakes by evaporation-induced self-assembly for all-solid-state batteries. J. Mater. Chem. A 2016, 4, 8091-8096. [CrossRef]

22. Ito, S.; Nakakita, M.; Aihara, Y.; Uehara, T.; Machida, N. A synthesis of crystalline $\operatorname{Li}_{7} \mathrm{P}_{3} \mathrm{~S}_{11}$ solid electrolyte from 1,2dimethoxyethane solvent. J. Power Sources 2014, 271, 342-345. [CrossRef]

23. Xu, R.; Xia, X.; Yao, Z.; Wang, X.; Gu, C.; Tu, J. Preparation of $\mathrm{Li}_{7} \mathrm{P}_{3} \mathrm{~S}_{11}$ glass-ceramic electrolyte by dissolution-evaporation method for all-solid-state lithium ion batteries. Electrochim. Acta 2016, 219, 235-240. [CrossRef]

24. Ziolkowska, D.A.; Arnold, W.; Druffel, T.; Sunkara, M.K.; Wang, H. Rapid and Economic Synthesis of a Li7 $\mathrm{PS}_{6} \mathrm{Solid}_{\mathrm{Electrolyte}}$ from a Liquid Approach. ACS Appl. Mater. Interfaces 2019, 11, 6015-6021. [CrossRef]

25. Yubuchi, S.; Uematsu, M.; Deguchi, M.; Hayashi, A.; Tatsumisago, M. Lithium-Ion-Conducting Argyrodite-Type Li $\mathrm{PS}_{5} \mathrm{X}(\mathrm{X}=$ Cl, Br, I) Solid Electrolytes Prepared by a Liquid-Phase Technique Using Ethanol as a Solvent. ACS Appl. Energy Mater. 2018, 1, 3622-3629. [CrossRef]

26. Zhou, L.; Park, K.-H.; Sun, X.; Lalère, F.; Adermann, T.; Hartmann, P.; Nazar, L.F. Solvent-Engineered Design of Argyrodite $\mathrm{Li}_{6} \mathrm{PS}_{5} \mathrm{X}(\mathrm{X}=\mathrm{Cl}, \mathrm{Br}$, I) Solid Electrolytes with High Ionic Conductivity. ACS Energy Lett. 2018, 4, 265-270. [CrossRef]

27. Chida, S.; Miura, A.; Rosero-Navarro, N.C.; Higuchi, M.; Phuc, N.H.; Muto, H.; Matsuda, A.; Tadanaga, K. Liquid-phase synthesis of $\mathrm{Li}_{6} \mathrm{PS}_{5} \mathrm{Br}$ using ultrasonication and application to cathode composite electrodes in all-solid-state batteries. Ceram. Int. 2018, 44, 742-746. [CrossRef]

28. Rangasamy, E.; Liu, Z.; Gobet, M.; Pilar, K.; Sahu, G.; Zhou, W.; Wu, H.; Greenbaum, S.; Liang, C. An iodide-based Li $\mathrm{P}_{2} \mathrm{~S}_{8} \mathrm{I}$ superionic conductor. J. Am. Chem. Soc. 2015, 137, 1384-1387. [CrossRef]

29. Phuc, N.H.H.; Hirahara, E.; Morikawa, K.; Muto, H.; Matsuda, A. One-pot liquid phase synthesis of $(100-x) \mathrm{Li}_{3} \mathrm{PS}_{4}-\mathrm{xLiI}$ solid electrolytes. J. Power Sources 2017, 365, 7-11. [CrossRef]

30. Phuc, N.H.H.; Yamamoto, T.; Muto, H.; Matsuda, A. Fast synthesis of $\mathrm{Li}_{2} \mathrm{~S}_{-} \mathrm{P}_{2} \mathrm{~S}_{5}-\mathrm{LiI}$ solid electrolyte precursors. Inorg. Chem. Front. 2017, 4, 1660-1664. [CrossRef]

31. Yamamoto, T.; Phuc, N.H.H.; Muto, H.; Matsuda, A. Preparation of $\mathrm{Li}_{7} \mathrm{P}_{2} \mathrm{~S}_{8}$ I Solid Electrolyte and Its Application in All-Solid-State Lithium-Ion Batteries with Graphite Anode. Electron. Mater. Lett. 2019, 15, 409-414. [CrossRef]

32. Arnold, W.; Buchberger, D.A.; Li, Y.; Sunkara, M.; Druffel, T.; Wang, H. Halide doping effect on solvent-synthesized lithium argyrodites $\mathrm{Li}_{6} \mathrm{PS}_{5} \mathrm{X}(\mathrm{X}=\mathrm{Cl}, \mathrm{Br}, \mathrm{I})$ superionic conductors. J. Power Sources 2020, 464, 228158. [CrossRef]

33. Li, J.; Liu, W.; Zhang, X.; Ma, Y.; Wei, Y.; Fu, Z.; Li, J.; Yan, Y. Heat treatment effects in oxygen-doped $\beta$-Li ${ }_{3} \mathrm{PS}_{4}$ solid electrolyte prepared by wet chemistry method. J. Solid State Electrochem. 2021, 1-11. [CrossRef]

34. Takada, K.; Aotani, N.; Kondo, S. Electrochemical behaviors of Li+ ion conductor, $\mathrm{Li}_{3} \mathrm{PO}_{4}-\mathrm{Li}_{2} \mathrm{~S}-\mathrm{SiS} 2$. J. Power Sources 1993, 43-44, 135-141. [CrossRef]

35. Nagamedianova, Z.; Hernández, A.; Sánchez, E. Conductivity studies on LiX-Li $2 \mathrm{~S}_{-} \mathrm{Sb}_{2} \mathrm{~S}_{3}-\mathrm{P}_{2} \mathrm{~S}_{5}\left(\mathrm{X}=\mathrm{LiI}\right.$ or $\left.\mathrm{Li}_{3} \mathrm{PO}_{4}\right)$ glassy system. Ionics 2006, 12, 315-322. [CrossRef]

36. Mo, S.; Lu, P.; Ding, F.; Xu, Z.; Liu, J.; Liu, X.; Xu, Q. High-temperature performance of all-solid-state battery assembled with 95(0.7 $\left.\mathrm{Li}_{2} \mathrm{~S}-0.3 \mathrm{P}_{2} \mathrm{~S}_{5}\right)-5 \mathrm{Li}_{3} \mathrm{PO}_{4}$ glass electrolyte. Solid State Ion. 2016, 296, 37-41. [CrossRef]

37. Hayashi, K.T.A.; Tatsumisago, M.; Minami, T.; Miura, Y. Structural Change Accompanying Crystallization in the Lithium lon Conductive $\mathrm{Li}_{2} \mathrm{~S}_{-} \mathrm{SiS}_{2}-\mathrm{Li}_{3} \mathrm{PO}_{4}$ Oxysulfide Glasses. J. Ceram. Soc. Jpn. 1999, 107, 510-516. [CrossRef]

38. Huang, B.; Yao, X.; Huang, Z.; Guan, Y.; Jin, Y.; Xu, X. Li $\mathrm{PO}_{4}$-doped $\mathrm{Li}_{7} \mathrm{P}_{3} \mathrm{~S}_{11}$ glass-ceramic electrolytes with enhanced lithium ion conductivities and application in all-solid-state batteries. J. Power Sources 2015, 284, 206-211. [CrossRef] 
39. Eckert, Z.Z.H.; Kennedy, J.H. Structural Transformation of Non-Oxide Chalcogenide Glasses. The Short-Range Order of $\mathrm{Li}_{2} \mathrm{~S}-\mathrm{P}_{2} \mathrm{~S}_{5}$ Glasses Studied by Quantitative ${ }^{31} \mathrm{P}$ and ${ }^{6,7} \mathrm{Li}$ High-Resolution Solid-state NMR. Chem. Mater. 1990, 2, 273-279. [CrossRef]

40. Gobet, M.; Greenbaum, S.; Sahu, G.; Liang, C. Structural Evolution and Li Dynamics in Nanophase $\mathrm{Li}_{3} \mathrm{PS}_{4}$ by Solid-State and Pulsed-Field Gradient NMR. Chem. Mater. 2014, 26, 3558-3564. [CrossRef]

41. Tao, Y.; Chen, S.; Liu, D.; Peng, G.; Yao, X.; Xu, X. Lithium Superionic Conducting Oxysulfide Solid Electrolyte with Excellent Stability against Lithium Metal for All-Solid-State Cells. J. Electrochem. Soc. 2016, 163, A96-A101. [CrossRef]

42. Wang, R.X.X.; Li, H.; Chen, L. Oxygen-driven transition from two-dimensional to three-dimensional transport behavior in $\beta-\mathrm{Li}_{3} \mathrm{PS}_{4}$ electrolyte. Phys. Chem. Chem. Phys. 2016, 18, 21269-21277. [CrossRef] [PubMed]

43. Machida, N.; Yoneda, Y.; Shigematsu, T. Mechano-chemical Synthesis of Lithium Ion Conducting Materials in the System $\mathrm{Li}_{2} \mathrm{O}-\mathrm{Li}_{2} \mathrm{~S}-\mathrm{P}_{2} \mathrm{~S}_{5}$. J. Jpn. Soc. Powder Powder Metall. 2004, 51, 91-97. [CrossRef]

44. Xie, D.; Chen, S.; Zhang, Z.; Ren, J.; Yao, L.; Wu, L.; Yao, X.; Xu, X. High ion conductive $\mathrm{Sb}_{2} \mathrm{O}_{5}$-doped $\beta$-Li $\mathrm{L}_{3} \mathrm{PS}_{4}$ with excellent stability against Li for all-solid-state lithium batteries. J. Power Sources 2018, 389, 140-147. [CrossRef]

45. Zhu, Y.; He, X.; Mo, Y. Origin of Outstanding Stability in the Lithium Solid Electrolyte Materials: Insights from Thermodynamic Analyses Based on First-Principles Calculations. ACS Appl. Mater. Interfaces 2015, 7, 23685-23693. [CrossRef] 